Asia Pacific Journal of Contemporary Education and Communication Technology

ISBN (eBook): 9780994365682 I IS5N : 2205-6181

Year: 2018, Volume: 4, I5sue: 2

\title{
UNDERSTANDING TEACHERS' UTILISATION AND IMPACT OF A VIRTUAL LEARNING ENVIRONMENT: A MULTIPLE-CASE STUDY IN POST-PRIMARY SCHOOLS IN MALAYSIA
}

\author{
Ruzana Tukimin \\ Trinity College Dublin, Ireland / Ministry of Education, Malaysia \\ Corresponding Email: tukiminr@tcd.ie
}

\begin{abstract}
In line with the vast development of information and communication technology (ICT) and the aim to increase access to education, many nations have introduced teaching and learning that are supplemented with a cloud-based virtual learning environment (VLE). This study is designed to examine the extent of VLE utilisation in Malaysian post-primary national schools. Despite profuse amount of VLE-related programmes, the Malaysian government's national audit findings reported low usage of the VLE. While previous studies have investigated reasons for the underutilisation, focus on gaining a complete understanding behind teachers' utilisation of VLE and its impact on teachers' professional practice is still limited. This research is based on a multiple-case study design, utilising interviews, classroom observations and a survey in an attempt to get a complete understanding of the topic regarding teachers' utilisation of VLE. This study explores the relationships between continuing professional development (CPD) sessions and teacher change as well as teachers' belief. Findings from this study is aimed at providing rich data that enables in-depth understanding of the topic, and that which contributes to valuable recommendations that may be used specifically to improve VLE utilisation in Malaysian post-primary national schools. The findings will also provide important reference for the general academic society regarding a case study research focusing on the utilisation and impact of VLE, especially on a nationwide implementation.
\end{abstract}

Keywords: Impact of Virtual Learning Environment, Multiple-case Study, Teachers'

Belief, Teachers' Professional Practice, Utilisation of Virtual Learning

Environment.

\section{Introduction and Background}

The rapid development of ICT together with on-going increment in the number of internet users worldwide have resulted in increased opportunities for greater knowledge and information accessibility (UNESCO Bangkok, 2015; Wallet \& Valdez, 2014). As ICT becomes increasingly important, many nations have responded by making efforts to transform school education from the traditional face-to-face, teacher-oriented teaching and learning to a student-centred environment that goes beyond the classroom, as well as exposing students to pedagogical approaches that encourage interactivity and the development of 21st century skills (Ministry of Education Malaysia, 2013; Robertson, 2016; Teoh, 2015).This study is designed to examine the extent of VLE utilisation in Malaysian post-primary national schools, which refer to the government-funded schools in the country. In line with the evolution of ICT and the aim to increase access to education, since 2012 teaching and learning in all national schools are 
supplemented with a cloud-based virtual learning platform called Frog VLE (Ministry of Education Malaysia, 2013; Soon, 2014). This study is instigated by the fact that despite profuse amount of VLE-related programmes, the Malaysian government's national audit findings reported that at the end of 2013, usage of the Frog VLE was only at $5 \%$ of the actual capacity (National Audit Department Malaysia, 2013).

\section{Literature Review}

The introduction of ICT has brought enormous changes in different aspects of human lives. ICT in the modern world helps to improve governance, services, work productivity and communication (ITU Telecommunication Development Bureau, 2016). In education, ICT offers the potential for a revolution in pedagogical approach and learning experiences, as well as access to a variety of educational resources (Kozma, 2011). The late $20^{\text {th }}$ century, particularly the mid-1990s have seen many governments around the world investing in digital technology as well as an increase in the number of strategic plans and policies on ICT in education. For instance, the USA launched the National Education Technology Plan and the Technology Literacy Challenge, the UK implemented the National Grid for Learning, New Zealand introduced the ICT Strategic Framework for Education, the Republic of Ireland began with Schools IT in 2000 and Singapore commenced with the Masterplan for ICT in Education (Chua, 2012; Johnston, 2014; Jones \& Cowie, 2011; Ministry of Education, 1997; Yeung et al, 2012). Just as digital technology progresses rapidly, the ICT strategic plans and policies also evolve accordingly. For example, the central idea of the strategic plans and policies used to be about introducing computers and multimedia applications as accepted tools for teaching and learning. However nowadays, policymakers and educational stakeholders are establishing more emphasis on promoting the internet and mobile devices that allow students to gain knowledge and skills in a self-directed, self-paced learning via a virtual learning environment (Chua, 2012; Sa'Don, Dahlan, \& Zainal, 2013; Soon, 2014).

\subsection{ICT Integration and Teachers' Professional Practice}

Since education is a crucial process for human resource development, there are various studies and evaluations being conducted in relation to the integration of ICT for teaching and learning. Some studies and evaluations focus on the implications of ICT integration on students, being the end-receiver of such educational initiatives. On the other hand, there are also studies that highlight the teachers, as they are perceived as important change agents that implement policy and curriculum in practice, and with whom the students generally spend most of their schooling years (Carlson, 2016; Donnelly, McGarr, \& O’Reilly, 2011; Tangas, 2014; Umar \& Hassan, 2015). Previous studies on the impact of ICT on teachers have indicated that they experienced improvements in their professional practice (Tangas, 2014; Tunmibi et al, 2015; Umar \& Hassan, 2015; Wang at al, 2014). Currently, there has been no formal definition of 'teachers' professional practice' but researchers and scholars have referred to professional practice as responsibilities associated with many different aspects of teaching including planning and preparation of lessons, managing the classroom environment, communication with students and parents, as well as other obligations such as collaboration, professional development and administration (Bahagian, 2009; Danielson, 2008; The Teaching Council Ireland, 2012).

To illustrate the positive impact of ICT on teachers, Hegedus, Dalton and Tapper (2015); Umar and Hassan (2015); and Tunmibi et al. (2015) indicated that with ICT integration, teachers in their studies found that certain learning concepts could be explained more effectively. For instance, ICT enables teachers to use $3 \mathrm{D}$ visualisation to explain the organs of a human body, or show videos of people, places and languages spoken in other countries. Integration of ICT in education has also allowed teachers to implement more student-centred activities such as inquiry-based and project-based learning (Garrett Dikkers, 2015; Hegedus et al., 2015; Tunmibi et al., 2015; Umar \& Hassan, 2015). According to Garrett Dikkers (2015), teaching and learning 
that incorporates a VLE can allow the students to investigate the subject content and discuss their understanding of a lesson with their classmates and teacher, via blogs or discussion boards in the VLE. Teachers in the same study also reported that they found themselves to be more organised and reflective on their daily instructional strategies, replacing ineffective methods with a greater diversity of technology tools to support teaching and learning. Meanwhile, Carlson (2016) highlighted that the teachers and school administrators in his study capitalised on the common software that they were using, to create abundant opportunities for formal and informal collaborations and sharing of ICT in education practices. Simin and Sani (2015) reported that teachers in their study were able to benefit from the teaching resources available in the VLE platform accessible to them, by using or adapting the resources to design interesting and engaging lessons that suit their students.

\subsection{ICT Implications on Teacher-Student Relationship}

The exponential growth of ICT coupled with easier access to the world wide web have led to the demand for more student-centred learning and digital classrooms as well as VLE to support the development of 21st century skills (Kong et al., 2014; Prensky, 2012; Soon, 2014). Consequently, there is anticipation for the role of teachers to change compared to the traditional teaching role and related methods employed in the 2oth century and earlier. Traditionally, the teacher is perceived as the direct content provider for the students (Ministry of Education Malaysia, 2013). Previous studies have suggested that students' learning goals may be achieved via personalised learning through collaborative and interactive activities (Scott, 2015). Furthermore, Salvador et al, (2017) reported that based on their study, personalised learning which is one of the attributes of VLE, has shown to be an optimiser of effective learning for students. In order to support students with a range of competencies and skills needed to succeed in modern global societies, teaching and learning focus more on interactive learner-led activities that create greater opportunities for inquiry-based learning, enabling students to develop 21st century skills involving critical thinking, creativity, collaboration and communication (Scott, 2015; Tondeur, Forkosh-Baruch et al, 2016; Voogt \& Plomp, 2010). As a result, teachers in 21st century classrooms act as facilitators who grant their students opportunities to engage in interactive learning with their peers (Morley, 2015; Scott, 2015).

When teachers become facilitators, they are no longer the focal point for information in the classroom. In contrast, knowledge acquisition in 21st century classrooms is a shared process, with the students exploring for meaningful information via individual and group tasks while the teacher monitors and gives feedback on the students' findings. (Carlson, 2016; Morley, 2015; Yin, 2013). Yin (2013) suggested that this shared process is positive because it helps to develop a sense of belonging and group dynamic. Nevertheless, in spite of the crucial transformed role of facilitators who monitor and provide feedback to the students' learning, Comas-Quinn, de los Arcos and Mardomingo(2012, p. 139) highlighted that a common experience pointed out by many teachers in their study on VLE implementation was that they had to spend more time than before in communicating with students, to the extent that a few teachers indicated that the "pastoral role has escalated" or "for some students learning has become dependent rather than independent". Similarly, Simin and Sani(2015) reported that the teachers in their study became frustrated because they realised that the students were too dependent and not taking responsibility for their own independent learning. The occurrence of this scenario will defeat the purpose of integrating ICT in education, particularly as the opportunity for synchronous and asynchronous teaching and learning made available via a VLE initiative is meant to encourage students to take charge of their learning at their own pace anytime and anywhere (Chargois, 2014; Ministry of Education Malaysia, 2013; Scott, 2015; Tunmibi et al., 2015). Thus, taking into account the changing role of teachers in 21st century teaching and learning, it is vital that teachers have the capability to appropriately blend between ICT integration and face-to-face sessions. Teachers need to develop the knowledge and skills regarding when and how to 
integrate which technology to support teaching and learning. This is important so that students are exposed to activities that can encourage them to adopt more active roles in their own learning without depending too much on the teachers.

\subsection{Use of a VLE in Teaching and Learning}

According to Laurillard (2005), a VLE can be used to provide access to five types of processes in relation to teaching and learning, namely narrative media, to assist understanding or apprehension of concepts, interactive media for investigating and exploring further information related to the lesson, communicative media for synchronous and asynchronous discussions, debates, instructions and announcements, adaptive media for experimenting and practising knowledge and skills acquired from the lesson and finally productive media for expressing and presenting ideas, findings as well as teachers' lesson plans. Nonetheless, studies have indicated that the use of a VLE is "predominantly in narrative and interactive modes to offer students access to digital content" (Lameras et al, 2012, p. 143). A similar description has been commonly used to describe the functions of a VLE, mainly as an online learning platform to support faceto-face teaching and improve students' learning process because it offers a repository for course documents, opportunity for collaborative, inquiry-based learning and a variety of communication options such as discussion forums and chat boxes (Álvarez et al, 2013; Chua \& Chua, 2017; FrogAsia, 2016; Yang et al, 2013).

Referencing Laurillard's (2005) descriptions of VLE use, Lameras et al. (2012) conducted another study investigating blended university teaching using VLE. Findings from the study revealed four categories of VLE use; information transfer (Category A), application and clarification of concepts (Category B), exchange of ideas, as well as investigation and sharing of resources (Category $\mathrm{C}$ ) and collaborative knowledge creation as well as development of process awareness and skills (Category D). Category A emphasises the usage of VLE to provide students with 'any time' and 'any place' access to administrative and subject-related content. Teaching and learning is content-oriented with the teachers viewing VLE as "an efficient, one-stop repository for items" (Lameras et al., 2012:145). Category B is described as an extension of Category A whereby apart from presenting students with the subject-related content materials, VLE functions as a medium to engage the students in tasks involving analysis and practical application of the subject content or theories. Apart from that, VLE use in Category B also emphasises on assessments, interactions and feedback to gauge the students' understanding and performance in relation to the subject content. Here, the teacher plays an important role as the students' digital proxy in guiding and giving responses regarding conceptual understanding of the subject. As a result, despite using the VLE to blend teaching and learning, Categories A and $\mathrm{B}$ are still considered to be adopting a teacher-focused, content-oriented approach (Lameras et al., 2012).

In Category C, the focus of VLE use is "to help students negotiate, further develop and change their understanding through engagement with tasks that encourage open-ended interaction between peers as well as the teacher" (Lameras et al., 2012, p. 147). The teacher's priority in Category $\mathrm{C}$ is to provide opportunities for the students to explore and express their opinions, whilst engaging with and potentially debating the topic with their peers. Category D expands the features of Category $\mathrm{C}$ by encouraging small group or team collaborations enroute to facilitating students into building and participating in a learning community (Lameras et al., 2012). Hence, Categories C and D shift from a teacher-focused to a student-centred approach in teaching and learning with VLE. (Scott, 2015) suggested that in the aspirations of the 21st century teaching and learning, emphasis is on student-centredness to support the students' development into active, independent and lifelong learners. Thus, in line with the aspirations, the utilisation of a VLE should reflect the descriptions of either Category C or Category D. 


\subsection{Teacher ICT Integration Model}

Donnelly et al.(2011) presented a model of teacher ICT integration as illustrated in Figure 1, which was extended from previous literature and studies on issues affecting teachers' use of educational technology such as by Ertmer(1999), Siorenta and Jimoyiannis (2008) and Zhao, Pugh, Sheldon, and Byers(2002). Based on the Teacher ICT Integration model, 'empowerment' or 'ownership' represents teachers who positively treat ICT as providing them with a great avenue to implement innovative and interesting educational activities with their students. In contrast, 'helplessness' or 'fatalism' refers to teachers who believe that they do not have the capacity to do anything about the ICT in education resources made available to them.

\section{EMPOWERMENT/OWNERSHIP}

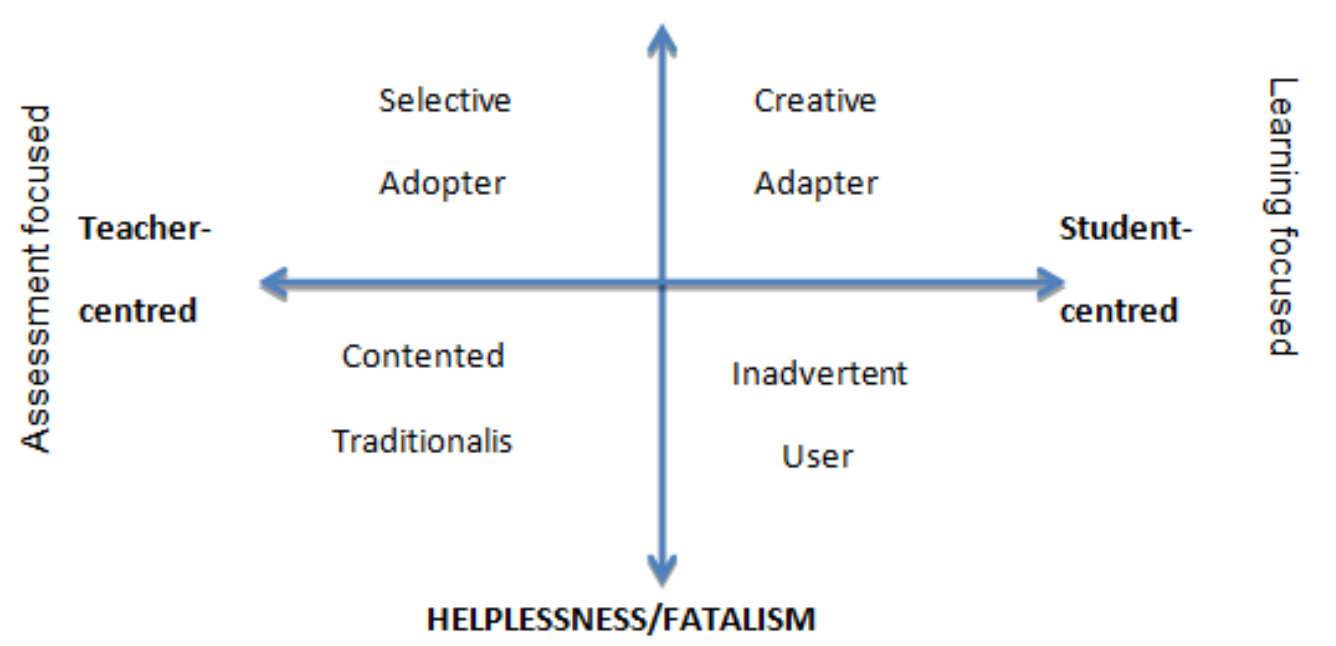

Figure 1: Teacher ICT Integration Model (Donnelly et al., 2011, p. 1477)

In relation to 'learning' versus 'assessment', Donnelly et al. (2011) suggested that teachers who focus more on assessment tend to adopt teacher-centred teaching and learning in order to impart as much content as possible to the students. Therefore, these teachers are usually unable to effectively integrate ICT in their teaching and learning. However, teachers on the opposite spectrum of the model implement more student-centred activities because they believe that teaching and learning should develop students' capabilities in relation to the subject matter (Donnelly et al., 2011). The teacher ICT integration model divides teachers according to four categories based on their educational beliefs, demonstration of Technological, Pedagogical and Content Knowledge (TPACK) and sense of purpose in relation to utilising ICT in education (Donnelly et al., 2011). Teachers who are contented traditionalists (CT) are more inclined to conduct teacher-centred and assessment-focused activities because they are driven by "extrinsic factors such as the curriculum, the principal, school management etc." Donnelly et al. (2011:1478). CTs often maintain traditional teaching practices because they either do not see how technology can assist them in delivering the content and pedagogy to the students, or they do not know how to integrate technology in teaching and learning.

The second group of teachers is called the selective adopter (SA), who despite having a good sense of ownership of the resources and activities, they choose for the lesson, as well as knowledge regarding which technology should be used to support teaching and learning, these teachers often find themselves confined to a more rigid assessment system. Consequently, these teachers will continue to integrate ICT in their teaching and learning, but only select digital resources that they believe will help their students "to do better in their final assessment" (Donnelly et al., 2011:1478). In the third category, the name inadvertent user (IU) suggests a 
group of teachers who only use ICT in education due to external factors such as school culture and peer pressure. Thus, although IUs integrate ICT in their teaching and learning, the integration is however involuntary in nature. Finally, the fourth group is called the creative adapter (CA), referring to teachers who are strong believers of student-centred learning approaches. CAs are able to utilise a wide-range of educational resources to help students gain better understanding of the content or subject matter. Furthermore, teachers who are CAs demonstrate the knowledge to blend appropriate technological tools with strategies and activities to teach technology-enhanced lessons (Donnelly et al., 2011).

The Teacher ICT Integration model is therefore beneficial for policymakers and stakeholders who seek to identify and embark on strategies to increase the utilisation of educational technology initiatives. This is because the descriptors provided in the model give a clear picture of how teachers presently relate themselves in relation to ICT integration for teaching and learning. Thus, policymakers and other relevant stakeholders are able to plan and carry out suitable follow-up measures. For instance, as suggested by Donnelly et al. (2011), pedagogical professional development courses will help teachers in the categories of CT and IU to move to the upper quadrants (CT to SA, IU to CA). The pedagogical professional development courses can be conducted at various points such as school-level in-house training and continuing professional development (CPD) sessions, also other sessions at district, state, national or international levels. In the meantime, according to Donnelly et al. (2011), the transitions from SA to CA or CT to IU require changes in environmental factors or other mandated changes. These changes include examples such as policy reforms, improvements in curriculum and assessment systems as well as the school culture. Hence, changes in environmental factors demand substantial decisions from the policymakers or the school authorities before such transitions can take any effect.

\subsection{Teachers' Beliefs and Continuing Professional Development (CPD)}

Soon 2014, p. 16emphasised that it is very important to get the "buy-in from all stakeholders" in order to successfully implement VLE or other ICT in education initiatives. As an important stakeholder in the education system, teachers need to be exposed to training and CPD sessions that highlight the advantages of ICT for teaching and learning as well as addressing how to integrate ICT in education. Teachers' decisions related to their professional practice, such as regarding the selection of pedagogical strategies and resources, including whether or not to incorporate teaching and learning with technology, are partly influenced by their beliefs on what they think students will find engaging and helpful for their learning(Howard et al, 2016; Kim et al, 2013). In a study investigating the relationship between teachers' beliefs and their participations in CPD, de Vries, van de Grift and Jansen (2013) reported that there was a positive association between student-centred beliefs and teachers' participation in CPD activities. Specifically, this finding indicates that the more teachers are inclined towards student-oriented pedagogy, the more they participate in the three types of CPD activities defined for the study, namely updating tasks, reflecting on their work, and collaborating with their colleagues (de Vries et al., 2013). In the meantime, Siew Ming, Azman and Joyes(2010:2) reported that based on their review of the Smart School initiative implemented by the Ministry of Education (MOE) Malaysia, integration of ICT into professional practice requires "teachers who themselves understand and believe in the capacity of the new technologies to transform learning in positive ways". This data is also supported in another study conducted by Howard et al, (2015). Findings from the study suggested that teachers must hold the belief that integration of ICT does support the teaching and learning outcomes, before they are willing to conduct technology-enhanced lessons (Howard et al., 2015). Hence, when aiming for buy-in, it is necessary to gain trust from the stakeholders by convincing them with the potential benefits that students, as well as the teachers themselves can reap from the VLE or other ICT in education initiatives. 
Ertmer et.al.(2012) suggested that "the best way to bring more teachers on-board is not by eliminating more first-order or the tangible barriers, but by increasing more knowledge and skills, which in turn have the potential to change attitudes and beliefs". Therefore, in order to try changing the attitudes and beliefs, teachers must be given the opportunity to participate in CPD and hand-holding sessions. It is also important that the CPD sessions must be suitably tailored to include knowledge on how to utilise the technology to enhance education. This is vital so that teachers are aware of particularly the advantages of the technology, and can confidently maximise the potential output and outcome for teaching and learning. Otherwise, if teachers are neither convinced nor comfortable, they tend to resort to using VLE or any other ICT in education initiatives at a superficial level or in a less meaningful way, as depicted in previous studies such as those conducted by Johnson-Martin(2012) and Won (2010).

\section{Methodology}

This study seeks to gain an in-depth understanding of the teachers' perspective regarding the utilisation of VLE in the Malaysian post-primary national school context. Besides that, this study also focuses to explore the impact of VLE utilisation on the teachers. A multiple-case study design is adopted for data collection in this study. The multiple-case study involves interviews, classroom observations and a survey within each case study in an attempt to get a complete understanding of the topic. Specifically, apart from a survey questionnaire, data collection in each case study school also includes one semi-structured interview with the school administrator, three semi-structured interviews involving three teachers nominated by the school administrator based on a set criteria provided by the researcher, three classroom observations involving each teacher involved in the interview and three sessions of group interview with students from the classes involved in the observations (four students on voluntary basis per session). A total number of eight post-primary national schools in one particular state in Malaysia have been identified as the case study schools. Taking into consideration the various types of post-primary national schools available in Malaysia, this study attempts to involve participants from some of the different backgrounds including schools that have been recognised as High Performance Schools (HPS) by the MOE Malaysia. The selection of schools was also carried out in consultation with the Educational Technology Division and the State Education Department, based on the schools' performance in relation to the utilisation of the VLE (emphasis on active and consistent utilisation).

\section{1 Data Analysis}

As this is a multiple-case study involving eight schools, data collected from each school will firstly be analysed separately as single-case studies. Within each school, analysis will be carried out to identify similarities and differences between different teachers' experiences in utilising Frog VLE. Data gathered from interviews with the school administrator and students as well as via classroom observations and survey will triangulate, support and complement all findings in relation to teachers' utilisation and the impact of the VLE. When data collection and analysis for each case have been completed, the researcher may then conduct a cross-case examination between the different schools. Again, the researcher may want to compare between cases to look for similarities and differences with reference to the objectives of this study. This will help to provide potentially expansive descriptions that may help the researcher to gain in-depth and a complete understanding of the case. In addition, since schools involved in the case study include three post-primary national schools that have received accreditation as High Performance Schools, and five other post-primary national schools, the cross-case will also examine the similarities and differences in relation to the teachers' utilisation of Frog VLE between the socalled exemplary schools and the other national schools. Results from this particular comparison are potentially beneficial, especially for MOE Malaysia. 


\section{Conclusion}

In line with the growing importance of ICT in the $21^{\text {st }}$ century, there is continuous emphasis on educational technology due to the desire to equip students with what is deemed necessary to prepare them to survive in life and excel as a future workforce for the country. These are evident from the ongoing investments, policies and roadmaps of ICT in education, as well as the incorporation of more up-to-date technology such as the VLE to help transform teaching and learning to be more ubiquitous, meaningful and learner-centred, with better access to educational resources for both the students and teachers. With regard to teachers, they interpret and translate policies in action, as well as facilitate the use of the digital learning resources to optimise students' learning experiences. Introducing new ICT infrastructure and programmes often result in interference or change to the teachers' professional routine. Hence, educational policymakers, principals and heads of academic institutions, programme managers and other related stakeholders need to understand factors that contribute to teachers' change in beliefs and attitude. As depicted by the Teacher ICT Integration model, having a sense of ownership or empowerment will contribute to a higher possibility of technology integration in teaching and learning. Nevertheless, it is also important to identify the driving force that motivates teachers to utilise the VLE initiative. The Teacher ICT Integration model also contains useful descriptors that help to gauge the teachers' beliefs and standpoint in relation to ICT integration for teaching and learning. Data from the mapping between the teachers' standpoint and the model, as well as other data gathered in this study will be useful for relevant stakeholders to conduct appropriate activities aimed at improving the utilisation of specifically the Frog VLE initiative, and generally increasing the integration of ICT in education. 


\section{References}

i. Álvarez, A., Martín, M., Fernández-Castro, I., \& Urretavizcaya, M. 2013. Blending traditional teaching methods with learning environments: Experience, cyclical evaluation process and impact with MAgAdI. Computers and Education, 68, pp. 129-140.

ii. Bahagian Pendidikan Guru., 2009. Standard Guru Malaysia. Kementerian Pendidikan Malaysia. [Online] Available at: https://doi.org/10.1007/s13398-014-0173-7.2

iii. Carlson, S. M., 2016. An Examination of Teacher Understandings of Technology Integration At The Classroom Level. sl.: University of Southern Maine.

iv. Chargois, T. D., 2014. Does Virtual Education Close the Gender Gap in the Sciences, Mathematics and English ?: Using Online Courses to Eliminate the Effects of Teachers 'Gender Bias. Lafayette: University of Louisiana.

v. Chua, C. H., 2012. ICT Masterplans in the Singapore Education System. [Online] Available at: http://www.unesco.org/new/fileadmin/MULTIMEDIA/HQ/ED/images/singapore.pdf

vi. Chua, Y. P., \& Chua, Y. P., 2017. How are e-leadership practices in implementing a school virtual learning environment enhanced? A grounded model study. Computers and Education, 109, pp. 109121.

vii. Comas-Quinn, A., de los Arcos, B., \& Mardomingo, R., 2012. Virtual learning environments (VLEs) for distance language learning: shifting tutor roles in a contested space for interaction. Computer Assisted Language Learning, 25(2), pp. 129-143.

viii. Danielson, C., 2008. The Handbook for Enhanching Professional Practice: Using the Framework for Teaching in Your School. sl: CENGAGE Learning.

ix. de Vries, S., van de Grift, W. J. C. M., \& Jansen, E. P. W. A., 2013. Teachers' beliefs and continuing professional development. Journal of Educational Administration, 51(2), pp. 213-231.

x. Donnelly, D., McGarr, O., \& O’Reilly, J., 2011. A framework for teachers' integration of ICT into their classroom practice. Computers and Education, 57(2), pp. 1469-1483.

xi. $\quad$ Ertmer, P., 1999. Addressing first- and second-order barriers to change: strategies for technology integration. Educational Technology Research and Development, 47(4), pp. 47-61.

xii. $\quad$ Ertmer, P. A., Ottenbreit-Leftwich, A. T., Sadik, O., Sendurur, E., \& Sendurur, P., 2012. Teacher beliefs and technology integration practices: A critical relationship. Computers and Education, 59(2), pp. 423-435.

xiii. FrogAsia., 2016. 1BestariNet. [Online] Available at: https://frogasia.com/en/1bestarinet/

xiv. Garrett Dikkers, A., 2015. The Intersection of Online and Face-to-Face Teaching: Implications for Virtual School Teacher Practice and Professional Development. Journal of Research on Technology in Education, 47(3), pp. 139-156.

xv. Hegedus, S. J., Dalton, S., \& Tapper, J. R., 2015. The impact of technology-enhanced curriculum on learning advanced algebra in US high school classrooms. Educational Technology Research and Development, 63(2), pp. 203-228.

xvi. Howard, S. K., Chan, A., \& Caputi, P., 2015. More than beliefs: Subject areas and teachers' integration of laptops in secondary teaching. British Journal of Educational Technology, 46(2), pp. $360-369$.

xvii. Howard, S. K., Ma, J., \& Yang, J., 2016. Student rules: Exploring patterns of students' computerefficacy and engagement with digital technologies in learning. Computers and Education, Volume 101, pp. 29-42.

xviii. ITU Telecommunication Development Bureau., 2016. Background on The Strategic Planning for The Union for 2016-2019. Geneva: International Telecommunication Union.

xix. Johnson-Martin, P., 2012. The Effect of Training on Teacher's Computer Self-Efficacy and Technology Practices: A Descriptive Study. sl: University of Phoenix. 
xx. Johnston, K. T., 2014. The Development and Implementation of ICT Policy for Schools in the Irish Post-Primary Context : A Critical Analysis. s.l.: University of Limerick.

xxi. Jones, A., \& Cowie, B., 2011. Evaluation approaches for a national ICT initiative: The example of laptops for New Zealand teachers. Educational Research for Policy and Practice, 1O(1), pp. 3-15.

xxii. Kim, C., Kim, M. K., Lee, C., Spector, J. M., \& DeMeester, K., 2013. Teacher beliefs and technology integration. Teaching and Teacher Education, 29(1), pp. 76-85.

xxiii. $\quad$ Kong, S. C., Chan, T.-W., Griffin, P., Hoppe, U., Huang, R., Shengquan Yu, Y.,2014. E-learning in School Education in the Coming 10 Years for Developing 21st Century Skills: Critical Research Issues and Policy Implications. Journal of Educational Technology \& Society, 17(1), pp. 70-78.

xxiv. $\quad$ Kozma, R., 2011. The Technological, Economic, and Social Contexts for Educational ICT Policy. In Shafika Isaacs, ed.Transforming education: The power of ICT policies. UNESCO, pp 3-15.

xxv. $\quad$ Lameras, P., Levy, P., Paraskakis, I., \& Webber, S., 2012. Blended university teaching using virtual learning environments: Conceptions and approaches. Instructional Science, 4O(1), pp. 141-157.

xxvi. Laurillard, D., 2005. Rethinking university teaching : a conversational framework for the effective use of learning technologies. London : RoutledgeFalmer.

xxvii. Ministry of Education., 1997. Smart School flagship: The Malaysian Smart School - A Conceptual. Government of Malaysia. sl.: sn.

xxviii. Ministry of Education Malaysia, 2013. Malaysia Education Blueprint 2013-2025 (Preschool to PostSecondary Education). Putrajaya: Kementerian Pendidikan Malaysia.

xxix. $\quad$ Morley, G., 2015. The impact of ICT on teaching in design and technology at key stage two. sl.: University of Huddersfield.

xxx. National Audit Department Malaysia, 2013. Auditor General's Report: Government's Financial Statement, Financial Management For The Year 2013 and Activitiesof The Federal Ministries/Departments and Management of The Government Companies Series 3.

xxxi. $\quad$ Prensky, M., 2012. From digital natives to digital wisdom : hopeful essays for 21st century learning. Thousand Oaks, Calif. : Corwin.

xxxii. $\quad$ Robertson, J.,2016. Moray House School of Education Election Briefings Digital Education Building a critical understanding of technology in everyday life. [Online] Available at:http://www.ed.ac.uk/files/atoms/files/electionbriefing2-digital-education-29-0316.pdf?utm source=Briefing\&utm medium=DigitalEd2\&utm content=election\&utm campaign $=$ MorayHouseBriefing

xxxiii. Sa'Don, N. F. B., Dahlan, H. B. M., \& Zainal, H. B., 2013. Derivation for design of Virtual Learning Environment (VLE) framework for Malaysian schools. 2013 International Conference on Research \& Innovation in Information Systems (ICRIIS), p. 570.

xxxiv. Salvador, P. T. C. de O., Mariz, C. M. S., Fernandes, M. I. D., \& Santos, V. E. P., 2017. Virtual learning object and environment: a concept analysis. Revista Brasileira de Enfermagem, 70(3),pp. 572-579.

xxxv. Scott, C. L., 2015. The Futures of Learning 3: what kind of pedagogies for the 21st century?Education Research and Foresight. Paris, France: sn.

xxxvi. Siew Ming, T., Azman, H., \& Joyes, G., 2010. Supporting Smart School Teachers' Continuing Professional Development in and through ICT: A model for change. International Journal of Education and Development Using Information and Communication Technology, 6(2).

xxxvii. Simin, G., \& Sani, I. M., 2015. Effectiveness of ICT Integration in Malaysian Schools : A Quantitative Analysis. International Research Journal for Quality in Education, 2(8),pp. 1-12.

xxxviii. Siorenta, A., \& Jimoyiannis, A., 2008. Physics instruction in secondary schools: An investigation of teachers' beliefs towards physics laboratory and ICT. Research in Science \& Technological Education, 26(2),pp. 185-202.

Soon, S. T., 2014. Leveraging Virtual Learning Environment to Scale Up Quality Teaching and Learning in Malaysia. Asia-Pacific Collaborative Education, 10(1), pp. 1-17. 
xl. Tangas, J.,2014. Measuring the Impact of the Digital Education Revolution on the ICT Capability of the National Teaching Workforce. ICICTE Proceedings, 343.

xli. Teoh, B. H., 2015. 1BestariNet: A Malaysian Experience. In Central Asia Symposium on ICT in Education 2015 Fostering an Enabling Environment for Teacher Innovation: From Policy to Practice, pp. 1-41.

xlii. $\quad$ The Teaching Council Ireland, 2012. Code of Professional Conduct for Teachers. sl.: sn.

xliii. Tondeur, J., Forkosh-Baruch, A., Prestridge, S., Albion, P., \& Edirisinghe, S, 2016. Responding to challenges in teacher professional development for ICT integration in eduation. Journal of Educational Technology and Society, 19(3), pp. 110-120.

xliv. Tunmibi, S., Aregbesola, A., Adejobi, P., \&Ibrahim, O., 2015. Impact of E-Learning and Digitalization in Primary and Secondary Schools. Journal of Education and Practice, 6(17), pp. 53-58.

xlv. Umar, I. N., \& Hassan, A. S. A., 2015. Malaysian Teachers' Levels of ICT Integration and Its Perceived Impact on Teaching and Learning. Procedia - Social and Behavioral Sciences, 197(February), pp. 2015-2021.

xlvi. UNESCO Bangkok, 2015. Central Asia Symposium on ICT in Education 2015 Fostering an Enabling Environment for Teacher Innovation : From Policy to Practice. In Central Asia Symposium on ICT in Education 2015 Fostering an Enabling Environment for Teacher Innovation: From Policy to Practice pp. 1-41.

xlvii. Voogt, J., \& Plomp, T. 2010. Innovative ICT-supported pedagogical practices: Results from the international study of information technology in education. Journal of Computer Assisted Learning, 26(6),pp. 449-452.

xlviii. Wallet, P., \& Valdez, B., 2014. ICT in Education in Asia: A comparative analysis of ICT integration and $e$ - readiness in schools across Asia. Montreal, Quebec, Canada: UNESCO-UIS.

xlix. Wang, S. K., Hsu, H. Y., Reeves, T. C., \& Coster, D. C., 2014. Professional development to enhance teachers' practices in using information and communication technologies (ICTs) as cognitive tools: Lessons learned from a design-based research study. Computers and Education, Volume79,pp. 101115 .

1. Won, S. S., 2010. Individual and Organizational Factors Influencing Korean Teachers' Use of Technology. sl.: Columbia University.

li. Yang, Y. T. C., Chuang, Y. C., Li, L. Y., \& Tseng, S. S., 2013. A blended learning environment for individualized English listening and speaking integrating critical thinking. Computers and Education, Volume 63,pp. 285-305.

lii. Yeung, A. S., Taylor, P. G., Hui, C., Lam-Chiang, A. C., \& Low, E. L, 2012. Mandatory use of technology in teaching: Who cares and so what? British Journal of Educational Technology, 43(6), pp. 859-870.

liii. Yin, L. S., 2013. Digitalizing the Malaysian Classroom: Barriers, Insights and Feasibility. Jurnal Pengajian Media Malaysia, 15(1),pp. 75-90.

liv. Zhao, Y., Pugh, K., Sheldon, S., \& Byers, J. L., 2002. Conditions for classroom technology innovations. Teachers College Record, 104(3),pp. 482-515. 